\title{
Sprawozdanie
}

\section{Międzynarodowa Konferencja nt.: Global Security, International Law and Humanitarian Action in the World in Transition, Szczecin, 21-22 października 2010 r.}

W dniach od 21 do 22 października 2010 r. w Hotelu Radisson Blu w Szczecinie odbyła się I Międzynarodowa Konferencja „Global Security, International Law and Humanitarian Action in the World in Transition”. W gronie głównych organizatorów znalazło się m.in. Stowarzyszenie Edukacji Społecznej i Prawnej „Ius et Ratio”, Zachodniopomorski Zarząd Okręgowy Polskiego Czerwonego Krzyża oraz Uniwersytet Szczeciński.

Głównymi blokami tematycznymi konferencji były strategie bezpieczeństwa organizacji międzynarodowych oraz Polski i Niemiec, dopuszczalne formy użycia siły we współczesnym prawie międzynarodowym, jak również międzynarodowe prawo humanitarne konfliktów zbrojnych i praktyczne aspekty współpracy cywilno-wojskowej. W związku z powyższymi założeniami dotyczącymi zakresu tematycznego projektu, przedsięwzięcie było rzadką okazją do spotkania naukowców zajmujących się problematyką interwencji $\mathrm{w}$ prawie międzynarodowym oraz międzynarodowym prawem humanitarnym, przedstawicieli sił zbrojnych państw NATO oraz organizacji humanitarnych.

Konferencja rozpoczęła się od wystąpień wprowadzających zatytułowanych „Bezpieczeństwo globalne w polityce zagranicznej Polski i Niemiec”, w których to J. Bleicker - Konsul Generalny RFN w Gdańsku oraz Ł. Polinceusz z Biura Bezpieczeństwa Narodowego zaprezentowali oficjalne stanowisko oraz strategie władz obu państw w tej materii.

W pierwszym panelu zatytułowanym „Europejska i transatlantycka polityka i strategia bezpieczeństwa z punktu widzenia Warszawy, Berlina i Brukseli“, poza wskazanymi już wcześniej referentami zasiedli również gen. E. Ramms - były głównodowodzący Sił Sojuszniczych NATO w centralnej Europie i Afganistanie, prof. dr M. Kaim z Niemieckiego Instytutu Polityki Międzynarodowej i Bezpieczeństwa (Fundacja „Nauka i Polityka”) 
w Berlinie oraz prof. dr hab. P. Policastro z Katedry Prawa Konstytucyjnego i Integracji Europejskiej na Wydziale Prawa i Administracji Uniwersytetu Szczecińskiego. Pomimo występujących pomiędzy panelistami różnic, wynikających głównie z pełnionych funkcji, wszyscy podzielili zdanie, iż poddawanym stale rewizji strategiom politycznym kształtowanym w stolicach europejskich brakuje spójności i dostosowania do realiów obszarów konfliktowych czy to w Afganistanie, Iraku czy np. w Afryce Północnej. Gen. Ramms zauważył, iż często zapominamy, iż sam Pakt Północnoatlantycki nie jest li tylko sojuszem militarnym i obronnym, ale i wspólnotą wartości, które bardzo rzadko są poddawane dyskusji w państwach będących członkami organizacji, co następnie ma wpływ na aktywność sojuszników w różnych częściach świata.

Drugi panel - „Interwencja humanitarna”, „ «Odpowiedzialność za ochronę», «uderzenie prewencyjne» - formy indywidualnego i kolektywnego użycia siły w czasach nowych zagrożeń" - do udziału w którym zaproszenie przyjęli prof. dr hab. S. Dabrowa - były ambasador Rzeczypospolitej Polskiej m.in. w Jugosławii i Bułgarii oraz dr H. J. Heintze z Instytutu Międzynarodowego Prawa Humanitarnego na Uniwersytecie Ruhry w Bochum - ukazał smutną rzeczywistość stosunków międzynarodowych, gdzie treść deklaracji i rezolucji o charakterze prawnym przyjmowanych przez różnorakie instytucje i organizacje międzynarodowe, w tym Radę Bezpieczeństwa ONZ, w niewielkim zakresie odpowiada rzeczywistym potrzebom społeczności lokalnych, służąc w głównej mierze interesom politycznym i ekonomicznym wielkich mocarstw. Z drugiej strony dr H. J. Heintze wskazał, iż wypracowana w 2001 r. przez Międzynarodową Komisję o Interwencji i Suwerenności Państwa ONZ koncepcja „Odpowiedzialności za Ochronę” („Responsibility to Protect") sprawdziła się w okolicznościach kryzysu humanitarnego na Haiti w okresie po trzęsieniu ziemi na początku $2010 \mathrm{r}$.

Punktem wyjścia do dyskusji w trzecim panelu zatytułowanym „Prawa człowieka w polityce zagranicznej Polski i Niemiec” była znana w Polsce publikacja pod redakcją A. Bieńczyk-Missali i R. Kuźniara o podobnym tytule. Prof. zw. dr hab. A. Bałaban - Kierownik Katedry Prawa Konstytucyjnego i Integracji Europejskiej na Uniwersytecie Szczecińskim, prof. dr hab. J. Ciapała z tej samej uczelni, dr G. Kemper - były Prezes Krajowego Sądu Konstytucyjnego, Krajowego Sądu Administracyjnego w Saksonii Anhalt oraz G. L. Wille z Wydziału Prawa w Lipsku dyskutowali o wpływie praw 
podstawowych skatalogowanych w ustawach zasadniczych RFN i RP na aktywność obu państw w sferze międzynarodowej oraz odpowiedzialność funkcjonariuszy za ich naruszenie. W pewnym momencie - za przyczyną wystąpienia prof. J. Ciapały dyskusję zdominował temat zróżnicowanej pozycji obywateli polskich przynależących do mniejszości niemieckiej w Polsce oraz obywateli niemieckich uważających się za przedstawicieli mniejszości polskiej w Niemczech.

Drugi blok tematyczny poświęcony międzynarodowemu prawu humanitarnemu konfliktów zbrojnych otworzył panel zatytułowany „MPH - 60 lat Konwencji Genewskich - osiągnięcia i wyzwania”. Wzięli w nim udział dr Izabela Gawłowicz z Katedry Prawa Międzynarodowego na Uniwersytecie Szczecińskim, dr M. Marcinko z Katedry Prawa Międzynarodowego na Uniwersytecie Jagiellońskim, R. Borrmann z Uniwersytetu Europejskiego Viadrina we Frankfurcie oraz dr M. Mohr z Międzynarodowej Koalicji na rzecz Zakazania Broni Uranowej. Wywołał on żywą dyskusję pośród szerokiego grona oficerów Wielonarodowego Korpusu NATO - „Północny-Wschód” mającego siedzibę w Szczecinie, którzy wyrazili swoją wątpliwość co do adekwatności zasad klasycznego MPH do skomplikowanych realiów współczesnego pola walki, choćby w Afganistanie. Dyskusję na temat prawa humanitarnego kontynuowano w drugi dzień konferencji, gdzie w panelu „Międzynarodowe Prawo Humanitarne i „rules of engagement” w czasach asymetrycznych konfliktów zbrojnych” wzięli udział dr R. Grodzki z Instytutu Zachodniego w Poznaniu, dr M. Kun - Buczko z Wyższej Szkoły Administracji Publicznej w Białymstoku, mjr A. Królikowski - Kierownik Działu Postępowania Karnego Wojskowej Prokuratury Garnizonowej w Szczecinie oraz J. Kowalewski z warszawskiego Biura Instytucji Demokratycznych i Praw Człowieka OBWE.

Kolejne panele tematyczne miały również bardzo praktyczny charakter. W ramach trzeciego bloku dyskutowano o akcji humanitarnej oraz o różnych modelach współpracy cywilno-wojskowej. Przedstawiciele polskich i niemieckich sił zbrojnych, jak gen. prof. B. Pacek ze Sztabu Generalnego Wojska Polskiego, gen. F. H. U. Borkenhagen - doradca Fundacji Friedricha Eberta, były Szef Sztabu Planowania FMON RFN czy też gen. W. Skrzypczak - były Dowódca Wojsk Lądowych RP zgodnie przyznali, że bez długofalowego wsparcia ze strony klasy politycznej, ale i innych resortów - głównie edukacji, zdrowia, sprawiedliwości, ale i bez większej aktywności MSZ 
w dziedzinie realizacji projektów rozwojowych bardzo trudno będzie zrealizować jakiekolwiek pozamilitarne cele w tak zróżnicowanym kulturowo obszarze, jak np. Afganistan. Zdanie to potwierdzili pośrednio również inni, cywilni paneliści - dr T. Jaskułowski z Instytutu im. Hanny Arendt na Uniwersytecie Technicznym w Dreźnie czy też J. Szewczuk ze Stowarzyszenia Rozwoju Gospodarczego Gmin. Ciekawie w tym kontekście zabrzmiały wystąpienia B. H. Seiberta ze Sztabu Planowania FMON RFN, który przedstawił koncepcję reformy Bundeswehry służącej również dostosowaniu armii do nowych wyzwań oraz dr. P. Łubińskiego z Uniwersytetu Jagiellońskiego, który w swoim wystąpieniu dokonał analizy projektów rekoncyliacyjnych w Afganistanie jako przykładu współpracy podmiotów rządowych i pozarządowych.

Podsumowując krótko wnioski płynące $\mathrm{z}$ dwudniowej konferencji w Szczecinie stwierdzić należy, że zarówno Polska, jak i Niemcy - państwa będące członkami ONZ, Organizacji Paktu Północnoatlantyckiego, jak i Unii Europejskiej i uczestniczące regularnie w misjach pokojowych i stabilizacyjnych w najbardziej odległych częściach świata coraz częściej stają przed wyzwaniami o charakterze nie tylko politycznym czy militarnym. Już samo zaangażowanie sił zbrojnych poza granicami własnego kraju oparte na przepisach Rozdziału VII Karty Narodów Zjednoczonych budzi kontrowersje moralne, ale przede wszystkim formalnoprawne. Nawet w sytuacji gdy sama interwencja nie budzi większych wątpliwości, to dyskusyjne są na pewno formy aktywności wojska, rozumiane choćby jako dostosowanie tzw. „rules of engagement” do standardów MPH czy też zasady współpracy sił zbrojnych z organizacjami międzynarodowymi, pozarządowymi, agendami cywilnymi poszczególnych państw czy społecznościami lokalnymi.

Nie ulega wątpliwości, iż przebieg I Międzynarodowej Konferencji „Global Security, International Law and Humanitarian Action in the World in Transition", w tym również burzliwych dyskusji na sali i w kuluarach dowodzi potrzeby bardziej regularnych spotkań naukowców oraz praktyków celem poddawania analizie coraz bardziej skomplikowanych wyzwań, przed którymi stają polscy żołnierze - funkcjonariusze państwa polskiego, ale i inni - cywilni jego przedstawiciele. Możliwe, iż potrzeba ta zostanie choć w części zaspokojona w czasie ewentualnych kolejnych edycji tego projektu.

Na zakończenie warto zwrócić uwagę na fakt, iż przedsięwzięcie zostało zrealizowane dzięki wsparciu finansowemu Fundacji Współpracy Polsko- 
-Niemieckiej, Uniwersytetu Szczecińskiego oraz Władz Wydziału Prawa i Administracji tegoż Uniwersytetu.

Marcin Przybysz (Uniwersytet Szczeciński) 